Segun Omosule Ph. D.

Senior Lecturer, Department of English, Olabisi Onabanjo University, Ago Iwoye, Nigeria.

Corresponding Authors' e-mail: omosulesegun@gmail.com

\title{
Aesthetics in Biripo Musical Performance
}

\begin{abstract}
Music is a universal language. Biripo music, even when restricted to a group of people in the Ikale/llaje/Apoi milieux, is an embodiment of the consciousness of the folks that combines the art of the people with entertainment as a major cultural thrust, achieving religious indoctrination, and entrenching ethical values in the environment. This paper attempts an analysis of the musical performance of Zeblon Omoranmowo entitled: word hangs loose and bursts (Oro Ma Se Dugbe Dugbe o Be o) through an examination of the subject matter, themes and analogies that may constitute veritable sources of conflicts to the larger society and internal disquietude to individuals. The paper explores the stage performance through an examination of the persona, competence, interaction, talent and reception. While relying on aesthetics as a tool of explication, the study unveils the response of the audience finding expression in dancing, clapping and offer of monetary gift to band members and concludes that the musical performance fulfils the yearning of the folks for entertainment.
\end{abstract}

Keywords: Music, Biripo, Performance, Aesthetics, Ethical Values.

\section{Introduction}

Zeblon Okonrenpo Omoranmowo is the focus of the study. He was born in 1924 and hailed from Okunmo-Erinje area of Okitipupa Local Government area of Ondo State. His father named Chief Omoranmowo Adaja was a musician. His mother was named Mrs. Adeyenwi Omoranmowo. Zeblon attended U. N. A School Okunmo in 1936 and became a teacher in the same school after his education. He worked with the Colonial Police Force and retired after many years. He was a member of Aghomalo Biripo Group. However, he established his own band in 1948 named Awayemate Biripo Group. In 1983, the government of Alhaji Shehu Shagari, for the scathing criticism of the regime, sanctioned Zeblon. He was banned. The ban was later lifted but not without incessant harassments from security agency. It was not a surprise that Zeblon was a musician. His father was a musician. Zeblon must have begun his interest in music from infancy as it is with children of craftsmen whose children are automatically adepts in the fields of their fathers'.

A visit to Okunmo in 2009 was memorable. The study emanated from the researcher's visit to the musician immediately the road that linked Okunmo with Ode Irele was constructed. The visit coincided with his stage performance billed for later that day. It was not without Ifa divination from the musician too who also doubled as an Ifa priest in appreciation of the visit prelude to the stage performance. The researcher was particularly interested in a song that indicts promiscuous men and women entitled: Oma Wa o Lagbeka (Here Comes the Unstable Carrier) and the underlying conclusion that it is what one enjoys that kills. Of course, the musician and the researcher danced to the verbal renditions of some songs without the accompaniment of the instruments.

Biripo music is indigenous to the people of the enclave known as Ikale/Ilaje/Apoi. The music is the original form of entertainment that is known to every member of the area immediately after birth, growth and appreciation of the environment. It evolves along with the acquisition of the dialects of the area and it becomes a natural component of individuals that they can hardly be oblivious to its existence, no matter how poor, rich or religious. The school boys are exposed to the form of music at schools in the course of entertaining dignitaries during sports festivals and the cultural component of the performance may thrill the individual exceedingly.

Biripo music, in the Ikale/Ilaje/Apoi milieux, remains the custodian of the lore of the people, embodying 
their values at the moment while drawing its strength from the past that was untainted by greed, and pettiness but that was governed by total submission to the unwritten moral and religious beliefs of the people subsisting in the Ifa corpus. It embodies the social and cultural values such that indigenous musical performances are laced with charms that members of the audience can hardly resist but that compel the audience to marvel at the ingenuity of the singers as they are considered talented and elevated above the multitude in the society.

Many notable traditional musicians adopt the genre of Biripo. They include: Zeblon Omoranmowo, Chief Sunday Ibayemi and his Ariwa Malokun Biripo Band, Egbe Omoboye Biripo, Lelerekoko Band, Ojulere Band and others. Female members of the society have their genre and it is known as Asiko. Notable Asiko singers are Comfort Omoge, Cecilia Akinsehinwa, Iwalapo Lalu, and Felicia Obamuwasan. Their deployment of the Ikale/Ilaje/Apoi dialects is superlative, and much relevance is made on the Ifa corpus as a source of inspiration. At times, outright renditions of the songs in the Ifa corpus are made thereby exhibiting deep and spiritual references to issues that the listeners can consider deep, beautiful and instructive. Folks music is defined by Adeyeye Adesanya et al., as a kind of music that is associated with 'rural peasants' and therefore associated with 'traditional' people: 'it could be sacred or secular' (35).

The live performance of a folk music by Zeblon Omoranmowo invoked a feeling of awe. The enthralling rendition of a song that encapsulated various ingredients of conflicts in the agrarian society combined the twin-function of entertainment and sensitisation. Apart from the captivation of the audience by the movements of the drummers accompanied by the poetic and sonorous composition of the lead-singer, members of the audience are enlightened through the isolation of relevant and related issues in the agrarian society that could engender peaceful co-existence and conversely ignite society in a conflagration that may ruffle filial order, upset the honour and pride of the individual whose indiscretion may have exposed to the jeer and tear of even ordinary members of the society. The performance amounted to communication through aesthetics as a philosophical model of analysis; claiming that religious books and selfish personal pursuits are potential sources of danger to the larger society especially when restraints are not exercised in the application of primordial claims to modern realities by folks whose indiscretion could ignite inter-personal conflicts

The feeling of excitement and elevation was matched with sadness which emanated from the disconnect the totality of the performance, within the unrivalled expressions, symbols and parallels might assume and suffer as a result of the coded language. What else is the Ikale/Ilaje/Apoi dialect other than esoteric to the Nigerian society and the global society? The globalised society prides itself in the conquest of limitations, barriers or social boundaries consequent upon the emergence of the Internet and the ease at which ideas could become handy and available to global citizens within minutes of their expressions. However, certain limitations may beset the total internalisation of a performance from the standpoint of nuances, cultural barriers such as codes and signs, gestures and postures that may not be easily interpreted from other cultural divide.

The first wonder emanated from the crude-talent, a display of raw, uncanny dexterity that typifies the artist in the delivery of the musical performance. Even when the lead-singer may not be the sole-purveyor of the rendition, as other members of the team are significantly audible in their incredible back-up, Zeblon's exemplary display of talent, fluidity in appropriating relevant anecdotes and capability at controlling and directing the back-up are worthy of examination. From a folk-singer whose dexterity may not be rivaled, the need to define art becomes imperative as creativity may depend largely on the psychological wellbeing of the singer where talent and personal desire to make a mark may be instrumental in the composition of songs and annexation of images from the socio-economic realities of the environment. From the point of view of Machlis Joseph (1955), therefore, Zeblon could be said to have chosen a 'sensuous medium' finding expression in music and may be adjudged successful as it 'appeals to our mind, arouses our emotions, kindles our imagination, enchants our senses' (3).

The feeling of regret equally overwhelms the researcher. The beauty of the performance notwithstanding, it is apparent that the performance and the imports could elude many listeners even when they have the privilege of internalising the dialect, and are familiar with the genre, their inability to relate the analogies in the performance with visible conflicts in the global society might shut the door of semanticity from them. Knowledge, no doubt, comes in varied forms; the association with leading authorities such as Joseph Campbell (1988), T. S. Eliot (1965) and Sigmund Freud (1965) might have constituted a secret master-key to unlock every door of perception. Perhaps, this singular development might be responsible for inspirations and the power of discernment in gestating scoops in many fields by scholars over the years.

Zeblon seems to occupy the same position as these leading authorities in the preceding paragraph as he exhibits a competence that is peculiar to him in the genre and juxtaposes this on the stage in a performativity which he also successfully transfers to the audience. The appreciation of the performance by members of the audience achieves aesthetic uniformity laced with dancing, clapping and singing in an atmosphere of conviviality. The songs bring to the fore the need for caution and highlight other sources of conflicts that may be anathema to the evolvement of people, and which must be avoided in order to grow, and unencumbered by visible flaws. Such flaws may not have ready appeal as potential sources of conflicts even when they may mar peaceful-co-existence of individuals and the society at large.

Two issues readily subject the text to further scrutiny. The emotion within the singer, which he tries to 